\title{
Az országnevek mint márkanevek és szerepük az országmárkázásban: néhány eset a világból
}

\section{Country names as brand names, and their role in country branding: Some cases from all over the world}

\author{
PAPP-VÁRY ÁRPÁD FERENC
}

PAPP-VÁRY Árpád Ferenc: intézetvezető, Budapesti Metropolitan Egyetem, Marketing Intézet, Budapest; apappvary@metropolitan.hu

KULCSSZAVAK: országmárkázás, nemzetmárkázás, márkanév, marketingkommunikáció, országmárka

ABSZTRAKT: Bár a helymárkázással foglalkozóknak természetes, a laikusokat akár meg is botránkoztatja, ha egy ország nevére úgy tekintünk mint márkanévre. Pedig ugyanúgy működnek: egy-egy ország neve láttán vagy hallatán bizonyos asszociációk jelennek meg a fejünkben. Ezek aztán befolyásolják, hogy turistaként ellátogatunk-e ide, tőkebefektetöként invesztálunk-e, vagy éppen fogyasztóként megvásároljuk-e az adott ország termékeit.

De vajon megváltoztathatja-e egy ország a nevét, hasonlóan ahhoz, ahogy termékmárkák teszik időnként? Azt bizonyosan állíthatjuk, hogy előbbi nem olyan egyszerű, mint utóbbi, hiszen a földrajzi helyek neveinek, így az országokénak is többnyire messzire nyúló történelmi gyökerei vannak. A név kötődik az ott lakók életéhez, akik hozzászoktak ahhoz, ezért sem könnyű azt megváltoztatni.

Mégis, akadnak rá példák, melyeket márkázási szempontból is értelmezhetünk. Az egyik ilyen, amikor az új márkanévvel-országnévvel új kezdetet akarnak jelezni. Amikor például a gyarmatok kivívták függetlenségüket, első dolguk volt, hogy új neveket adtak maguknak. De hasonló történt az egykori Szovjetunió vagy Jugoszlávia felbomlásakor - a létrejövő utódállamok új nevet kaptak vagy éppen visszatértek régi nevükhöz.

A névváltás napjainkban is napirenden van egyes országok esetében. Ennek oka lehet például az, hogy az ország neve bonyolult, vagy az, hogy túlzottan hasonló egy másik ország nevéhez, így az országok versenyében hátrányos helyzetből indul.

Az ország nevének azért is kiemelt jelentősége van, mert ez az egyetlen biztos közös elem az ország kommunikációs kampányaiban - és a bölcsebb országok ezt ki is használják, akár a szlogenbe integrálva az ország nevét.

Jelen tanulmány az országmárkázás elméletének bemutatása után a fentieket járja körül, sok példával Európából és a világ más részeiből.

Árpád Ferenc PAPP-VÁRY: head of institute, Marketing Institute, Budapest Metropolitan University, Budapest; apappvary@metropolitan.hu

KEYWORDS: country branding, nation branding, brand name, marketing communications, country brand

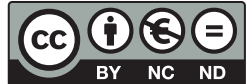


ABSTRACT: Today, it is widely accepted that "country brand councils" are established all over the world, including Hungary, and these bodies coordinate the strategic communications (or at least the marketing communications) of the country. It is also becoming more and more obvious that politicians discuss country branding and nation branding, and these terms appear in the public media, too.

Regarding the name of a country as a brand name is natural for place branding professionals, but it may offend those not familiar with this marketing practice. However, country names and brand names do cause the same reaction: when we see or hear a specific country name, we have certain associations in our mind. Then these associations help us decide whether we visit the place as a tourist, invest capital there, or purchase the products of the country.

Although the terms nation branding and country branding only appeared in 1996, there is an extensive literature dedicated to them, and organisations responsible for the coordination of country branding have been created in several countries.

The three main aims of country branding are: to attract more tourists to the country and increase their spending; increase the number and value of foreign investments in the country; and increase the international success of products originating from the country.

To this end, country branding harmonises strategic communications and marketing communications messages about the country. Its most important aspects include the building of the country image and a uniform visual and verbal identity.

Country slogans and country logos have been discussed in several publications, but brand names (country names) have not been in the focus of analyses, which is rather surprising as brand names are essential in commercial communications. Therefore this article examines this topic from a special perspective: Can a country change its name the way product brands do from time to time?

Changing a country name is most definitely a much more complicated issue than using a new product name, as geographical names (including country names) usually have long historical roots. These names are also strongly connected to the life of local inhabitants who have got used to them, therefore they are not easy to change.

Still, there are examples that could be analysed from the aspect of branding. In some cases the new brand name or country name is meant to symbolise a new beginning. For example, when colonies claimed their independence, the first thing to do was to create a new name for the country. And something similar happened when the former Soviet Union and Yugoslavia broke up - the newly formed successor states started to use new names, or returned to their old names.

Some countries still have changing their names on the agenda. Possible reasons include the complicatedness of the country name, or its similarities with other country names, resulting in disadvantages in the competition of countries.

A country name is also extremely important because it is the only common element in the communications campaigns of the country - and wise countries make advantage of this, sometimes even integrating the country name in their slogan.

\section{Bevezetés}

Ma már szinte természetes, hogy szerte a világon, így Magyarországon is, „országmárkatanácsok” alakulnak és müködnek, melyek az ország stratégiai kommunikációját vagy legalábbis marketingkommunikációját koordinálják. Egyre inkább magától értetődő az is, hogy politikusok országmárkázásról, nemzetmárkázásról beszélnek, vagy éppen a közéleti sajtóban tűnik fel a kifejezés.

Ám nem volt ez mindig így. Michel Girard francia akadémikus 1999-ben például a következőket írta (idézi Olins 2004b, 18.): „A rebranding (újramárkázás) 
ötlete Franciaországban a széles közvélemény által elfogadhatatlan lenne, mert közös érzés, hogy Franciaországnak mások az alapvonásai, mint egy vállalatnak. Egy vállalatot újra lehet márkázni, de egy országot nem. Elképzelhető, hogy egy mosópornak más nevet adunk - amit egyébként gyakran meg is tesznek. Az újramárkázás normális módszer a fogyasztói termékek körében, de hogy ugyanez lenne az országok esetében is? (...) Egy ország méltóságot hordoz magában, nem úgy, mint egy piacon kapható termék. (...) Franciaországban elképzelhetetlen, hogy Chirac megkísérelje az ország újramárkázását." Nos, a fentiekkel szemben például Nagy-Britanniában Tony Blair korábbi kormányfö is használta az ezredforduló környékén a „nation branding” (nemzetmárkázás), illetve a „nation rebranding” (nemzet-újramárkázás) kifejezéseket. Valójában ugyanis „semmi újdonság nincs abban, hogy egy nemzetből márka lesz. Csak maga a megnevezés, hogy »márka«, ez az új. A nemzeti imázs, a nemzeti azonosság, a nemzeti hírnév olyan kifejezések, amiket már régen használunk, és amelyek nem váltanak ki az emberekből olyan zsigeri utálatot, mint az a szó, hogy »márka«" - emeli ki Olins, a téma egyik neves szakértője A márkák címü könyvében (2004a, 168.).

Bár a márka szó jó néhány emberből még ma is zsigeri utálatot vált ki, az is kétségtelen, hogy legalább ennyien rajonganak a márkákért, sőt szeretik őket (Roberts 2004). Márkák nélkül ma már elképzelhetetlen egy átlagember napja, és maga a márka, illetve brand kifejezés is egyre jobban beépül a közbeszédbe (Papp-Váry 2013).

Térjünk azonban vissza az országok márkázására! A szakirodalom alapján a brit Simon Anholt volt az első, aki 1996-ban papírra vetette a nation branding, illetve a country branding (országmárkázás) koncepcióját, amikor saját bevallása szerint „kezdte unalmasnak találni, hogy gazdag vállalatoknak segít még gazdagabbá válni" (Rendon 2003). Így aztán a korábban multinacionális vállalatok (Coca-Cola, Nescafé) marketingjével foglalkozó Anholt úgy döntött, hogy egészen új vállalkozásba kezd: az országok márkázására fog szakosodni. Anholt ma is a terület első számú szakértője, akinek olyan könyvei jelentek meg, mint a Brand new justice - How branding places and products can help the developing world (2005), a Competitive identity - The new brand management for nations, cities and regions (2007), vagy a Places - Identity, image and reputation (2009).

Bár Anholt 1996-ban használta először a nemzetmárkázás fogalmát, mindez azonban nem jelenti azt, hogy ezelőtt ne foglalkoztak volna hasonló kérdésekkel, akár az elméletben, akár a gyakorlatban. Már 1993-ban megjelent egy könyv a helymarketingről (Kotler, Haider, Rein 1993), mely az országokat is külön tárgyalta (Marketing places: Attracting investment, industry, and tourism to cities, states and nations). A mü fó szerzője pedig nem más volt, mint a marketing ,atyja”, Philip Kotler. De ha tágabban nézzük, a nemzeti identitással mindig is foglalkozott a politikai földrajz, a nemzetközi kapcsolatok, a politikatudomány, a kulturális antropológia, a szociálpszichológia, a politikai filozófia, a nemzetközi jog, a szociológia és a történettudomány (Dinnie 2008). A marketingakadémikusok viszont érdekes módon figyelmüket sokáig nem az országmárkáknak szentelték, 
hanem az egyes országokból származó márkáknak (country-of-origin effect). Papadopoulos és Heslop (2002) például 766 jelentősebb publikációt számolt össze ebben a témában a megelőző 50 évből, ugyanakkor rámutatott arra, hogy magukról az egyes országok imázsáról nincsenek igazán jó felmérések.

A nagy áttörést a Journal of Brand Management 2002. évi nemzetmárkázási különszáma hozta, olyan neves szerzők publikációival, mint Kotler, Gertner, Papadopoulos, Heslop, Olins, Gilmore és Lodge, az előszót pedig nem más, mint Anholt jegyezte (Anholt 2002). 2004 novemberében pedig önálló akadémiai folyóirat jött létre Place Branding and Public Diplomacy névvel. Ezt követően egymás után jelentek meg a könyvek: Simon Anholt ismeretterjesztőbb írásai mellett egy másik brit szakértő, Keith Dinnie szerkesztésében megjelent egy komolyabb, ,akadémiaibb" mü is, a Nation branding (2008).

Hazánkban hasonló folyamatok történtek: bár az országmárka és az országmárkázás iránti igény régóta jelen van, sokáig nem így hívták. „Hosszú, szinte szakállasnak mondható története van ma már az országimázs tudatos formálására és fejlesztésére irányuló szakmai munkának és a különbözö törekvéseknek" - írták a Marketing és Menedzsment szaklap szerkesztői. Hogy mikor? 1996-ban! A millecentenárium évében a Marketing és Menedzsment (interjú)sorozatot szentelt az országimázsnak, melyben többek között Hankiss Elemér, Lengyel Márton, Serényi János, Szeles Péter, Takács Ildikó és az akkori művelődési és közoktatási miniszter, Magyar Bálint osztotta meg gondolatait. (Hankiss 1996; Lengyel 1996; Marketing és Menedzsment 1996a, 1996b; Szeles 1996).

A nem túl hosszú életű Országimázs Központ (2000-2002) mint állandó médiatéma aztán hozzájárult a szó még szélesebb körű elterjedéséhez. Ugyanezt eredményezte 2004 áprilisában Frei Tamás műsora a TV2-n az országimázsról (Frei 2004).

Az országmarketing kifejezése is már jó pár éve megjelent, többek között a régió- és településmarketing magyar nyelvü alapkönyvében, Piskóti, Dankó, Schupler és Büdy munkájában (1997, 25-26.), Kozma cikkében (1995, 38.), Kraftné és Fojtik írásában (1998) vagy Kandikó Régiómarketing című összefoglalásában $(2003,2$.$) .$

Az országmárkázás, illetve az „ország mint márka”-megközelítés megjelenése hazánkban a 2000-es évek elejére tehető, melyben élenjáróak voltak Szeles (2001), valamint Papp-Váry (2003) tanulmányai. Az országmárkázás helyesebb értelmezéséhez két nemzetközi konferenciára is szükség volt: az egyiket a Budapesti Közgazdaságtudományi és Államigazgatási Egyetem szervezte 2004 májusában (Országmárkázás az EU-csatlakozás tükrében), a másikat pedig a Demos Magyarország 2006 novemberében (Country branding - Nemzetközi identitás és imázs - lásd Demos 2006). 2008-ban megalakult az Országmárka Tanács a 2176/2008. (XII. 18.) kormányhatározattal, mely megfogalmazta, hogy a tanács Magyarország egységes, pozitív külföldi megítélésének és megjelenítésének, valamint az egységes országmárka kialakításának és az országkép formálásának szakmai előkészítő, javaslattevő és véleményező fóruma. 
Ezzel párhuzamosan több doktori ( $\mathrm{PhD}$ ) disszertáció is született a témában, Papp-Váry (2007), Jenes (2012) vagy Szondi (2014) tollából. Utóbbi Magyarországról a téma legtöbbet idézett nemzetközi szaktekintélye, akinek komoly összefoglaló tanulmányai jelentek meg (Szondi 2007, 2008).

A nemzetközi és a magyar szerzők közt egyetértés van abban, hogy az országmárkázás három fö célja (és egyben a jó országmárka 3 fö előnye) a következő (Papp-Váry 2009):

1. A turizmus ösztönzése, turisták vonzása az adott országba.

2. Az országba jövő befektetések ösztönzése.

3. Az export fejlesztése, az ország termékeinek jobb külpiaci értékesítése.

Abban is egyetértés van, hogy mindezt egyértelműen segíti a koordinált (marketing)kommunikáció, illetve ennek részeként az egységes (ország)arculat. Több tanulmány foglalkozott ezért az országszlogenekkel (lásd például Khan 2014) és az országlogókkal (Lee, Rodriguez, Sar 2012), vagy épp mindkettővel (Hildreth 2013). Ugyanakkor meglepő módon egyetlen olyan tanulmány sincs, mely kifejezetten magával az országnévvel foglalkozna, annak hatását emelné ki az ország mint márka építésében. Jelen cikk ezért ezt a témát járja körül többféle szempontból, sok esettel Európából és a világ más részeiből.

\section{Első hallásra}

Ahogy a bevezetés utalt rá, az országneveket ugyanúgy értelmezhetjük, akár a márkaneveket. Ezek kiejtése után ugyanis az emberekben önkéntelenül is megjelenik egy kép. Ami a legkülönösebb, hogy ez még akkor is igaz lehet, ha soha nem hallottak elötte az adott országról. Elég azt a példát felhozni, amely szinte mindannyiunkkal megtörtént már külföldön járva: „Where do you come from?” - kaptuk a kérdést. „Hungary.” „What? Are you hungry?”

Hasonlóról számoltak be lengyelek is, akiknek úgy tűnik, kevésbé erős az országmárkája, mint Hollandiáé. Esetükben a fenti párbeszéd gyakran úgy hangzott, különösen a rendszerváltás után: „Where do you come from?” „Poland!” „Ah, Holland!"

Természetesen az, hogy viccek születnek egy ország nevével, nem feltétlenül jelenti azt, hogy a név rossz. Van viszont, amikor kifejezetten erről van szó - hogy a név problémás és ez hátrányt okoz: kevesebb turista jön az országba, mint az az ország látnivalói alapján várható lenne, kevesebb külföldi beruházás érkezik, vagy éppen kevesebben vásárolják meg az ország termékeit.

Egy klasszikus brandet nézve ilyenkor megoldás lehet a márkanév cseréje. Egy ország esetében azonban mindez nem ilyen egyszerü. A földrajzi helyek elnevezéseinek többnyire történelmi gyökerei vannak, legyen szó hegycsúcsokról, tavakról, tengerekről, városokról és különösen az országokról. A név kötődik az ott lakók életéhez, akik hozzászoktak ahhoz, ezért sem olyan egyszerű azt megváltoztatni. 


\section{Gyarmatnév helyett saját név}

Annak ellenére, hogy nem könnyü egy ország esetében a névváltás, azért akadnak rá példák, melyeket márkázási szempontból is értelmezhetünk. Az egyik ilyen, amikor az új márkanévvel-országnévvel egy új kezdetet akarnak jelezni. Amikor például a gyarmatok kivívták függetlenségüket, első dolguk volt, hogy új neveket adtak maguknak.

Volt olyan eset, amikor maga a gyarmatosító neve is szerepelt az ország nevében, és az a függetlenné válással eltűnt. Például:

- Új-Spanyolország - Mexikó (1821)

- Spanyol Kelet-India - Fülöp-szigetek (1898)

- Holland Kelet-India - Indonézia (1945)

- Francia Szudán - Mali (1960)

- Francia Togoföld - Togo (1960)

- Brit Guiana - Guyana (1966)

- Spanyol Guinea - Egyenlítői-Guinea (1968)

- Brit Honduras - Belize (1973)

- Holland Guiana - Suriname (1975)

- Portugál Guinea - Guinea-Bissau (1979)

Volt, hogy a gyarmatosító ország nevére ugyan nem volt ilyen egyértelmű utalás, de a névváltás fontos jelzés volt. Például:

- Sziám - Thaiföld (1949)

- Aranypart - Ghána (1957)

- Észak-Rhodesia - Zambia (1964)

- Nyasszaföld - Malawi (1964)

- Basutóföld - Lesotho (1966)

- Becsuánaföld - Botswana (1966)

- Kelet-Pakisztán - Banglades (1971)

- Ceylon - Srí Lanka (1972)

- Dahomey - Benin (1975)

- Ellice-szigetek - Tuvalu (1978)

- Gilbert-szigetek - Kiribati (1979)

- Új-Hebridák - Vanuatu (1980)

- Felső-Volta - Burkina Faso (1984)

Időnként pedig nem is egy névváltás történt, hanem több:

- Német Dél-Afrika (1884) - Délnyugat-Afrika (1915) - Namíbia (1990)

- Dél-Rhodesia - Rhodesia (1965) - Zimbabwe-Rhodesia (1979) - Zimbabwe (1980)

- Kongó Szabad Állam (1884) - Belga Kongó (1908) - Kongói Köztársaság (1960) - Kongói Demokratikus Köztársaság (1964) - Zaire (1971) - Kongói Demokratikus Köztársaság (1977)

- Francia Szomália - Afars és Issas (1967) - Dzsibuti (1977) 
Ezeknek a helyeknek nemcsak postai bélyegeiken kellett jelezniük a névváltást, hanem minden más szempontból is újra kellett kezdeniük mindent. Ezért ugyanúgy, ahogyan azt a 19. században európai elődeik tették, feltárták vagy sokszor kitalálták saját történelmüket. Zimbabwe például egy félig-meddig misztikus afrikai birodalom volt, körülbelül azon a területen, ahol a mai Zimbabwe fekszik. Az ókori Zimbabwe és a modern Zimbabwe közötti történelmi kapcsolat ugyan lényegében elhanyagolható, az érzelmi kötődés azonban fontos az itt élőknek (Olins 2004a).

\section{Utódállamok nehézségei}

A másik nagy márkanév-, illetve márkamegjelenési hullámot a kilencvenes évek elején láthattuk, amikor a Szovjetunióból több nemzet vált ki. Voltak persze közöttük nagy történelmi múlttal és hagyományokkal rendelkező országok, például Grúzia - amely ma inkább a Georgia nevet használja, ezzel is pozicionálva, megkülönböztetve magát. Mások azonban, mint az öt közép-ázsiai „,-sztán” (Üzbegisztán, Kirgizisztán, Türkmenisztán, Kazahsztán és Tádzsikisztán) korábban nem léteztek független államként.

Mindeközben Csehszlovákia is két részre szakadt, Csehországra és Szlovákiára - az más kérdés, hogy ezzel mennyien vannak tisztában. A szerző maga is tapasztalta, hogy amikor egy neves londoni egyetem oktatója 2008-ban előadást tartott Budapesten, a „Czechoslovakia” kifejezést használta...

De ha külön-külön nézzük a két államot, akkor sem egyszerű a helyzet. A csehek problémája, hogy országuk nemzetközi megnevezése meglehetősen hosszú: The Czech Republic. Egyes akadémikusok, brandingszakértők és a kormánytagok viszont úgy találták, hogy az országok köznapi megnevezésében lényegtelen az államforma. A turisták ugyanis általában nem a Spanyol Királyságba vagy az Ausztrál Nemzetközösségbe mennek nyaralni, hanem inkább a rövid nevet használják. Nem is beszélve Hong Kongról, ahol a hivatalos forma: Hong Kong Special Administrative Region of the People's Republic of China.

Bárhogy is, Csehországnak (legalábbis angol nyelven) csak a hivatalos megnevezése létezik, nincs rövid alakja. Ezért a fenti szereplők a Czechia nevet javasolták a The Czech Republic helyett. Csakhogy ez meg nagyon hasonlít Csecsenföldre, ami angolul úgy hangzik: Chechnya. (Igaz, utóbbi márkanevet még egyetlenegy állam sem ismerte el a világban.) A csehek másik része viszont az egykori Bohemia és/vagy Moravia megnevezést szeretné. Ez ugyan történelmileg helytálló lehetne, de a branding szempontjából valószínűleg rossz lépés, mert az átlagos világpolgár nem ilyen tájékozott a múlttal kapcsolatban és végképp nem értené, honnan is jönnek a csehek (Economist 2004). 
A szlovákoknak sincs könnyebb helyzetük. Őket ugyanis rendszeresen összekeverik Szlovéniával. Igaz ezt nyelvük sem könnyíti meg, Szlovákia hivatalos megnevezése ugyanis Slovenská republika.

Ha már a szlávok kerültek szóba, számukra a legnagyobb problémát mégis a szláv szó nemzetközi kiejtése okozza. A kevésbé műveltek ugyanis a slav kifejezést sokszor slave-nek ejtik. Ebből pedig arra következtetnek, hogy Jugoszlávia a rabszolgák országa - vagy legalábbis az volt, amíg még így hívták. Most viszont már hat önálló állam fekszik a területén: Szerbia, Montenegró, Horvátország, Szlovénia, Macedónia és Bosznia-Hercegovina. Sőt, ha úgy vesszük, Koszovóval együtt hét. Igaz, utóbbit sokan még nem ismerték el - az Európai Unió például 2008. február 18-án a tagországokra bízta, hogyan járnak el az ügyben.

\section{Névváltó kampányok}

A legérdekesebb eset a jugoszláv utódállamok közül márkanév szempontjából Macedóniáé. Az ország ugyanis a Jugoszláviától való elszakadása után a szerencsétlen hangzású Former Yugoslav Republic of Macedonia nevet volt kénytelen hivatalosan használni. Vagy még rosszabb esetben annak rövidítését, a FYROM-ot. Így kellett megjelennie a nemzetközi diplomáciai találkozókon, de még az Eurovíziós Dalfesztiválon is így konferálták fel az innen származó zenekart. A görög kormány kijelentette, hogy Macedónia - mint földrajzi terület - jóval nagyobb, mint a macedón állam, ráadásul nagyrészt Görögországhoz tartozik. A görögök ragaszkodása ha egyeseknek nem is szimpatikus, de márkázási szempontból érthető: nem szeretnék, ha Nagy Sándort és örökségét nem velük, hanem a macedón állammal kötnék össze az emberek, és - mondjuk turizmus céljából - azt keresnék fel. A macedónok viszont érthetően eredeti nevüket kívánják használni, amiért még kampányt is indítottak: „Don't you FYROM me! Say Macedonia!” azaz „Ne FYROM-ozz! Hívj Macedóniának!”, illetve „Call me by my name! Say Macedonia!” azaz „Szólíts a nevemen! Hívj Macedóniának!”

Egy másik, látszólag lényegesen nagyobb márka, pozitívabb imázsú ország esetében is felmerült a névcsere. Nagy-Britannia azt tapasztalta, hogy az egykori gyarmatokon megítélése sok szempontból negatív - és ehhez hozzájárul, hogy a „nagy” egyfajta birodalmi jelző az ország nevében. Bár az ország nevét nem cserélték le, az arculati anyagokon ma már többnyire csak a rövid nevet használják, azaz szimplán annyit: Britain (Papp-Váry 2005). Nagy-Britannia esetében már nem az első ilyen névváltásról van szó. Szerte a világon jól tudják, hogy a brit királyi házat Windsornak hívják. Ám ez csak 1917-től van így: akkor cserélték le ugyanis a Saxe-Coburg and Gotha nevet, amelynek az első világháborúban kifejezetten kellemetlenné vált német csengése és eredete.

Izgalmas eset Észtországé, amely egy időben igyekezett az Estonia angol elnevezést kerülni és inkább az Estlandot használni (lásd például Szondi 2007). 
Az Estonia névről ugyanis felmérések szerint sokaknak az 1994-ben Tallinn és Stockholm közt elsüllyedt komp tragédiája jutott eszébe, amikor 852-en vesztették életüket. Minderről később ráadásul játékfilm készült Balti vihar címmel, Donald Sutherland föszereplésével. Aztán a „balti vihar” elült, és az Estonia név maradt. A 2000-es évek elején azonban ismét felmerült az angol Estonia név cseréje. Mégpedig E-stoniára (E-Észtország), utalva arra, hogy az ország mennyire elöl jár az információtechnológiában. Mindehhez meg is volt a reális háttér, mert a McConnell International kutatása szerint az e-környezet terén már ekkor Tajvan és Észtország állt a világranglista első két helyén. Ráadásul az E-Észtország vízióként is kiválóan müködött: a polgárok tudták, hogy miért kell dolgozniuk, mitől lesz versenyképes országuk.

2008-ban egy másik balti ország, Litvánia is felvetette a névcserét (Reuters 2008). A kormányszóvivő mindezt azzal indokolta: „Angolul nagyon nehéz az ország nevét kiejteni és emlékezni rá”. A névcseréből a polgárok felháborodása és a média kritikája miatt nem lett semmi, de az ország szlogenje azért megszületett: Litvánia - Egy bátor ország.

Szintén az ország nevével játszott az a javaslat, melyet a pozicionálás egyik atyja, Al Ries javasolt Guetamalának. Véleménye szerint a közép-amerikai ország azzal különböztethetné meg magát legjobban, ha kiemelné, hogy a maja birodalom központja volt. Ehhez pedig nem kellene mást tennie, mint az ország nevében az l-t lecserélni y-ra: Guatemaya. Ez az ott élők számára is gyökereket jelentene, másrészt a turisták számára is egyértelmű jelzés lenne (Ries, Ries 2002,150.).

\section{Országnév a szlogenben}

Ha a szlogen szó eredetét keressük, térben és időben Galliába kell visszautaznunk. A sluagh-ghairm ott a csatakiáltást jelentette. Manapság, ha csatakiáltásként már nem is tekintünk rá, annyi biztos, hogy „a márkanévhez hasonlóan a szlogen is a márkaérték-építés rendkívül hatékony eszköze" - írja Kotler, a marketing atyja és Keller, a branding egyik legismertebb szakértője a Marketingmenedzsment címü könyvben (2012, 293.). A szlogen „feladata, hogy használható kapaszkodót vagy támpontot adjon a fogyasztónak annak megértéséhez, hogy mi rejlik a márka mögött, és mi teszi különlegessé” - emelik ki (Kotler, Keller 2012, 293.).

Sokan próbálták már megfejteni, milyen a jó szlogen, és általában a következő szempontok kerülnek elő (Papp-Váry 2013):

- Pozicionál.

- Egyértelmü üzenete van, átadja a termék „sztoriját”.

- Benne van a „fogyasztói, vevői” előny.

- Megkülönböztet: egyedi, eredeti.

- Pozitív konnotációt hordoz.

- Inspiráló: hogy megvásároljuk, illetve hogy többet akarjunk megtudni róla. 
- Aránylag rövid (legfeljebb 5 szó).

- Könnyü megjegyezni és elismételni.

- Jól működik együtt a logóval.

- Blikkfangos, szellemes.

- Hosszú távon használható, fenntartható.

A fentiek mellett van még egy szempont: szerencsés megoldás, ha a márkanév a szlogenbe kerül. Ez természetesen nem azt jelenti, hogy kizárólag az ilyen szlogenek müködnek jól. De az egyáltalán nem véletlen, hogy már David Ogilvy is megírta A reklámról című alapkönyvében (2001), hogy ha lehet, a reklám címsorába tegyük bele a márkanevet. Ugyanezt javasolja Paul Arden is, a Saatchi\&Saatchi reklámügynökség egykori kreatív igazgatója (2003). Bár ők mindezt a címsorokra írták, a szlogenekre ugyanúgy, sőt jobban is megállják a helyüket megállapításaik (lásd erről Papp-Váry 2013).

Ha mindez így van termékek esetében, akkor komoly esélye van annak, hogy azok az országok jó úton járnak, ahol a márkanév (azaz az ország neve) beépül a szlogenbe - legalábbis olyan szempontból, hogy egyértelműen azonosítani lehet a márkát, és a fogyasztók könnyebben megjegyzik a szlogent. A következő példák ilyenek:

- Smile! You are in Spain;

- 100\% Pure New Zealand;

- Incredible India;

- I feel love, I feel Slovenia;

- Britain is Great.

A legkülönlegesebb kétségkívül az utolsó. A kampányban ugyanis épp a Great szó lett kiemelve, ami ellentmond a korábban írtaknak, vagyis hogy Nagy-Britannia szabadulna a „nagy” jelzőtől. Paradoxonnak tünhet, de bizonyos szempontból ez a kampány is ebben kíván segíteni. Üzenetstruktúrája ugyanis úgy van felépítve, hogy nem azt emeli ki, hogy maga az ország, a birodalom területe a nagy, hanem hogy az örökség, a zene, a sport, a vállalkozás, az innováció vagy éppen a bevásárlás milyen nagy, azaz milyen nagyszerű lehetőségek vannak.

Hozzá kell tenni, a szlogenek kapcsán talán a kulcskérdés nem is maga a szlogen, hanem annak következetes használata. Vonatkozik ez mind a földrajzi kiterjedésre, mind az időtávra. „Ahogyan a világ összes McDonald's-ében Big Mac-et lehet venni, ugyanúgy kellene minden országban ugyanazt a szlogent terjeszteni" - mondta a Tourism New Zealand igazgatója, George Hickton (Pike 2007, 14.). Ha pedig ezt éveken, évtizedeken keresztül „mantrázzuk”, számíthatunk rá, hogy az előbb-utóbb megragad - ahogy a Nike „Just do it”-je. Ezzel szemben ha a szlogent kampányról-kampányra cserélgetjük, sok jót nem várhatunk.

Az országoknál ez talán még inkább fennáll, mint a klasszikus márkáknál. A normál brandek esetében is jellemző, hogy amikor jön egy új marketingvezető, az „ott akarja hagyni a keze nyomát”, ezért teljesen új szlogent, logót, marketingkommunikációs koncepciót talál ki. Ennek még nagyobb az esélye, ha nemcsak a marketingvezető, hanem a reklámügynökség is cserélődik. 
Az országok, régiók, városok esetében sajnos mindehhez hozzájárulhatnak a politikai játszmák is. Az új vezető már „csak azért is” meg akarja mutatni, hogy ő jobb, hogy ő más, hogy az ő ötletei sokkal jobbak. És ez nemcsak Magyarországra, hanem a világ szinte minden részére igaz. Steven például az Egyesült Államok tagállamainak szlogenjeit vizsgálta 1982-ben, 1993-ban és 2003-ban. Eredménye szerint a 47 szlogenből, amelyet 1982-ben használtak, csupán hat volt érvényben 1993-ban. Az 1993-ban vizsgált 43 szlogenből 2003-ban már csak 13-at használtak. 21 év lefolyása alatt csupán 6 szlogen maradt hủ az eredeti verzióhoz (Pike 2007).

\section{Összefoglalás}

Bár a nemzetmárkázás vagy országmárkázás fogalma csak 1996-ban jelent meg, mára kiterjedt szakirodalma van, és a gyakorlatban is egyre több országban jön létre az országmárka koordinációjáért felelős szervezet.

Az országmárkázás három fó célja, hogy több turista érkezzen az országba és azok többet költsenek, hogy nőjön a külföldi tőkebefektetések száma és értéke az országban, és hogy az országból származó termékek sikeresebbek legyenek a világpiacon.

Az országmárkázás ennek érdekében összehangolja az országról küldött stratégiai kommunikációs, marketingkommunikációs üzeneteket. Mindennek fontos része az arculatépítés, az egységes vizuális és verbális identitás. Míg az országszlogenekről és az országlogókról több publikáció is született, addig meglepő módon a márkanév (országnév) még nem került a vizsgálatok fókuszába. Pedig ha valami nem maradhat ki a kommunikációból, akkor az éppen a márkanév.

De lehetséges-e, hogy egy ország megváltoztassa a nevét, hasonlóan ahhoz, ahogyan a termékmárkák teszik időnként? Miként a cikk igazolta, akadnak rá példák. Az egyik ilyen, amikor az új márkanévvel-országnévvel új kezdetet akarnak jelezni. Amikor például a gyarmatok kivívták függetlenségüket, első dolguk volt, hogy új neveket adtak maguknak. De hasonló történt az egykori Szovjetunió vagy éppen Jugoszlávia felbomlásakor.

Miként a tanulmány rámutatott, a névváltás napjainkban is napirenden van egyes országok esetében. Ennek oka lehet például az, hogy az ország neve bonyolult, vagy éppen az, hogy túlzottan hasonló egy másik ország nevéhez, így az országok versenyében hátrányos helyzetből indul.

Az ország nevének azért is kiemelt jelentősége van, mert ez az egyetlen biztos közös elem az ország kommunikációs kampányaiban - és a bölcsebb országok ezt ki is használják, akár a szlogenbe integrálva az ország nevét. 


\section{Irodalom}

Anholt, S. (2002): Foreword to the special issue on country branding. Journal of Brand Management, 4., 229-239. http://doi.org/ctjqg8

Anholt, S. (2005): Brand new justice - How branding places and products can help the developing world. Elsevier Butterworth Heinemann, Oxford

Anholt, S. (2007): Competitive identity - The new brand management for nations, cities and regions. Palgrave Macmillan. Houndmills, Basingstoke, Hampshire

Anholt, S. (2009): Places - Identity, image and reputation. Palgrave Macmillan. Houndmills, Basingstoke, Hampshire

Arden, P. (2003): It's not how good you are, it's how good you want to be. Phaidon Press, London

Demos (2006): „Nation branding” azaz országimázs-formálás Európában. Melléklet a DEMOS Magyarország Alapítvány Country branding - Nemzetközi imázs és identitás konferenciájához, 2006. november 28., Budapest

Dinnie, K. (ed.) (2008): Nation branding - Concepts, issues, practice. Elsevier Butterworth-Heinemann, Oxford

Economist (2004): Renaming the Czech Republic. The Economist, május 20.

Frei T. (2004): Frei Dosszié - Magyar Imázs. TV2, 2004. április

Hankiss E. (1996): Találjuk ki Magyarországot avagy: egy tudós földönjáró álmai. Marketing és Menedzsment, 3., 62-64.

Hildreth, J. (2013): The joys and sorrows of logos and slogans in place branding. Place Branding and Public Diplomacy, 9., 217-222. http://doi.org/ben8

Jenes B. (2012): Az országimázs mérésének elméleti és gyakorlati kérdései - Az országimázs és az országmárka dimenziói és mérési modellje. Doktori értekezés. Budapesti Corvinus Egyetem, Budapest

Kandikó J. (2003): Régiómarketing. CEO magazin, 1., melléklet, 1-12.

Khan, S. (2014): Word play in destination marketing: An analysis of country tourism slogans. Team Journal of Hospitality and Tourism, 1., 27-39.

Kotler, P., Haider, D. D., Rein, I. (1993): Marketing places - Attracting investment, industry and tourism to cities, states, and nations. The Free Press, New York

Kotler, P., Keller, K. L. (2012): Marketingmenedzsment. Akadémiai Kiadó, Budapest

Kozma G. (1995): Városmarketing mint a helyi gazdaságfejlesztés egyik lehetséges eszköze. Tér és Társadalom, 9., 37-54.

Kraftné Somogyi G., Fojtik J. (1998): Helymarketing, turizmus-marketing, területfejlesztés. Marketing és Menedzsment, 3., 53-61.

Lee, S., Rodriguez, L., Sar, S.: The influence of logo design on country image and willingness to visit: A study of country logos for tourism. Public Relations Review, 4., 584-591. http://doi.org/bcn9

Lengyel M. (1996): Országkép (Imázs). Marketing és Menedzsment, 2., 4-6.

Marketing és Menedzsment (1996a): Országimázs - Interjú Takács Ildikóval. Marketing és Menedzsment, 4., 42-46.

Marketing és Menedzsment (1996b): Országimázs - Interjú Serényi Jánossal és Radnai Lászlóval. Marketing és Menedzsment, 5., 28-31.

Ogilvy, D. (2001): Ogilvy a reklámról. Park Kiadó, Budapest

Olins, W. (2004a): A márkák - A márkák világa, a világ márkái. Jószöveg Műhely, British Council, Budapest

Olins, W. (2004b): Branding the nation: The historical context. In: Morgan, N., Pritchard, A., Pride, R. (eds.): Destination branding - Creating the unique destination proposition. Elsevier Butterworth Heinemann, London, 17-25.

Papadopoulos, N., Heslop, L. A. (2002): Country equity and country branding. Journal of Brand Management, 4., 294-314. http://doi.org/fchdv8

Papp-Váry Á. F. (2003): „Brand-new image” vagy „New brand-image”? Hogyan használjuk a vállalati márkázás technikáit az ország mint márka felépítésében? Marketing és Menedzsment, 3., 4-11.

Papp-Váry Á. F. (2005): Rule Britanniából Cool Britannia. Az országmárkázás buktatói a szigetország példáján. In: Beszteri B. (szerk.): Fenntartható fejlődés, fenntartható társadalom és integráció. MTA Veszprémi Területi Bizottság, Kodolányi János Főiskola, Székesfehérvár, 253-263. 
Papp-Váry Á. F. (2007): Az országmárkázás szerepe és hatásai: Országimázs a kibővült Európai Unióban. Doktori értekezés. Nyugat-Magyarországi Egyetem Közgazdaságtudományi Kar, Gazdasági folyamatok elmélete és gyakorlata Doktori Iskola Marketing alprogram, Sopron

Papp-Váry Á. F. (2009): Országmárkázástól a versenyképes identitásig. Marketing és Menedzsment, 2., 4-19.

Papp-Váry Á. F. (2013): A márkanév ereje - Szempontok a sikeres brandépitéshez. Dialóg-Campus Kiadó, Budapest, Pécs

Pike, S. (2004): Destination brand positioning slogans - towards the developement of a set of accountability criteria. Acta Turistica. 16.

Piskóti I., Dankó L., Schupler H., Büdy L. (1997): Régió és településmarketing - egy tudatos koncepció a nemzetközi és hazai gyakorlat példáján. Miskolci Egyetem, Miskolc

Rendon, J. (2003): When nations need a little marketing. New York Times, november 23. http://www.nytimes.com/2003/11/23/business/business-when-nations-need-a-littlemarketing.html (Letöltés: 2016. február 21.)

Reuters (2008): Lithuania considers name change in makeover plan. Reuters, január 25.

Ries, A., Ries, L. (2002): The fall of advertising and the rise of PR. HarperCollins, New York

Roberts, K. (2004): Lovemarks - Jövő a márkák után. Magyar Könyvklub, Budapest

Szeles P. (1996): Önismeret és tükörkép, avagy álmaink és a külső valóság. Marketing és Menedzsment, 1., 33-36.

Szeles P. (2001): A hírnév ereje - Arculatelmélet. Alapítvány a Public Relations Fejlesztéséért, Budapest

Szondi Gy. (2007): The role and challenges of country branding in transition countries: The Central and Eastern European experience. Place Branding and Public Diplomacy, 1., 8-20. http://doi.org/dff3wq

Szondi Gy. (2008): Public diplomacy and nation branding: Conceptual similarities and differences. Discussion Papers in Diplomacy. Netherlands Institute of International Relations Clingendael. http://www.clingendael.nl/sites/default/files/20081022_pap_in_dip_nation_branding.pdf (Letöltés: 2016. február 21.)

Szondi Gy. (2014): European Union public diplomacy: Emerging concepts, strategies and practices. Doktori értekezés. University of Salzburg, Salzburg 
5 